\title{
PENGARUH KEPUASAN KONSUMEN TERHADAP LOYALITAS MEREK KARTU PRABAYAR IM3 PADA PEGAWAI KANTOR GUBERNUR SULAWESI TENGAH
}

\author{
Labandingi Latoki \\ Email: bandingiandi@yahoo.com
}

\begin{abstract}
ABSTRAK
Penelitian ini mengungkapkan pengaruh mutu produk, harga, service quality, emotional factor dan kemudahan mendapatkan produk terhadap loyalitas merek kartu prabayar IM3 pada pegawai Kantor Gubernur Sulawesi Tengah. Metode yang digunakan Penelilti bersifat Deskriptif Kausal dengan alat bantu koesioner terhadap 108 responden. Hasil penelitian ini membuktikan bahwa faktor mutu produk, harga, service quality, emotional factor dan kemudahan mendapatkan produk berpengaruh positif signifikan terhadap loyalitas merek kartu prabayar IM3 pada pegawai Kantor Gubernur Sulawesi Tengah. Kelima variabel ini berpengaruh sebesar 76,2\% terhadap loyalitas merek kartu prabayar IM3 pada pegawai Kantor Gubernur Sulawesi Tengah. dapat dijelaskan oleh faktor mutu produk, harga, service quality, emotional factor dan kemudahan mendapatkan produk. Sedangkan sisanya $23,8 \%$ dapat dijelaskan oleh faktor-faktor lain yang tidak diteliti dalam penelitian ini.

Kata Kunci: Loyalitas Merek, Mutu Produk, Harga, Service Quality, Emotional Factor dan Kemudahan Mendapatkan Produk.
\end{abstract}

\section{LATAR BELAKANG}

Kartu prabayar IM3 merupakan salah satu produk dari PT Indosat Tbk yang bergerak melayani pelanggan di bidang jasa telekomunikasi, produk ini sudah sangat dikenal oleh masyarakat Indonesia, mempunyai pelanggan yang banyak dan cukup diperhitungkan oleh para pesaingnya. kita ketahui bersama persaingan diantara produk sejenis akhir-akhir ini sangat ketat, baik dalam produk, harga, distribusi, promosi dan lain sebagainya, hal ini menuntut perusahaan untuk lebih kreatif dalam menarik perhatian konsumen. Salah satu upaya yang dilakukan dalam menghadapi persaingan ini PT Indosat Tbk dengan produk IM3 memberikan kualitas pelayanan yang terbaik kepada konsumen, kualitas pelayanan tersebut terdiri dari kualitas produk, harga, distribusi dan promosi. Hal ini dilakukan semata-mata bertujuan untuk mendapatkan kepuasan yang diinginkan konsumen, sehingga konsumen itu menjadi loyal dalam menggunakan produk yang dihasilkan. Kemampuan produk untuk memberikan kepuasan pada pemakainya akan menguatkan kedudukan atau posisi produk dalam benak konsumen, sehingga memungkinkan konsumen menjadikan pilihan pertama bilamana akan terjadi pembelian diwaktu yang akan datang. kualitas produk yang ditawarkan dan dari kartu prabayar IM3 diantaranya dengan memberikan fitur dan layanan yang tersedia di dalam kartu yaitu mulai dari sms, i-ring, transfer pulsa, IM3-access, GPRS, MMS, dan Confirence Call.

Giddens (2002) menyatakan bahwa loyalitas merek adalah pilihan yang dilakukan konsumen untuk membeli merek tertentu dibandingkan merek yang lain dalam satu kategori produk. Schiffman dan Kanuk (dikutip oleh Dinarty SH Manurung, 2009) juga mendefinisikan loyalitas merek sebagai preferensi konsumen secara konsisten untuk melakukan pembelian pada merek yang sama pada produk yang spesifik atau kategori pelayanan tertentu. Walaupun demikian, loyalitas konsumen terhadap merek berbeda dengan perilaku pembelian berulang ( repeat purchasing behavior). Perilaku pembelian berulang adalah tindakan pembelian berulang pada suatu produk atau merek yang lebih dipengaruhi oleh faktor kebiasaan dalam loyalitas konsumen, tindakan berulang terhadap merek 
tersebut dipengaruhi oleh kesetiaan terhadap merek (Kumar, 2002).

Sumarwan (dikutip oleh Dinarty SH Manurung, 2009) menambahkan bahwa loyalitas akan menyebabkan munculnya komitmen terhadap merek, yaitu kedekatan emosional dan psikologis dari seorang konsumen terhadap merek suatu produk. Giddens (2002) menyatakan bahwa konsumen yang loyal terhadap suatu merek memiliki ciri-ciri, yaitu memiliki komitmen pada merek tersebut, yakni kedekatan emosional dan psikologis seseorang konsumen terhadap suatu produk, dalam melakukan pembelian kembali produk tersebut tidak melakukan pertimbangan, selalu mengikuti informasi yang berkaitan merek tersebut serta mereka dapat menjadi semacam juru bicara dari merek tersebut dan mereka selalu mengembangkan hubungan dengan merek tersebut. Konsumen dengan loyalitas merek akan selalu mencari merek favoritnya dan kurang sensitif pada promosi yang kompetitif. Konsumen yang loyal akan menunda pembelian apabila merek produk yang ingin dibeli tidak tersedia atau habis. Di era persaingan yang semakin ketat ini, banyak faktor yang dapat mempengaruhi loyalitas konsumen, antara lain dengan memperhatikan kepuasan konsumen, kualitas jasa layanan terhadap konsumen, citra produk maupun perusahaan, dan kecilnya rintangan untuk berpindah (Mardalis, 2005; 134).

Berdasarkan uraian di atas, maka peneliti ingin melihat apakah pengaruh faktor-faktor kepuasan konsumen dapat mempengaruhi loyalitas merek pada kartu Indosat IM3. Untuk itu penulis tertarik untuk membuat penelitian dengan judul "Pengaruh Kepuasan Konsumen Terhadap Loyalitas Merek Kartu Prabayar IM3 Pada Pegawai Kantor Gubernur Sulawesi Tengah"

Permasalahan yang diangkat dalam penelitian ini adalah:

1. Apakah kepuasan konsumen yang terdiri dari Mutu Produk, Harga, Service Quality, Emotional Factor dan Kemudahan mendapatkan produk berpengaruh secara simultan terhadap loyalitas merek kartu prabayar IM3 Pada Pegawai Kantor Gubernur Sulawesi Tengah?

2. Apakah Mutu Produk berpengaruh signifikan terhadap loyalitas merek kartu prabayar IM3 Pada Pegawai Kantor Gubernur Sulawesi Tengah?

3. Apakah Harga berpengaruh signifikan terhadap loyalitas merek kartu prabayar IM3
Pada Pegawai Kantor Gubernur Sulawesi Tengah?

4. Apakah Service Quality berpengaruh signifikan terhadap loyalitas merek kartu prabayar IM3 Pada Pegawai Kantor Gubernur Sulawesi Tengah?

5. Apakah Emotional Factor berpengaruh signifikan terhadap loyalitas merek kartu prabayar IM3 Pada Pegawai Kantor Gubernur Sulawesi Tengah?

6. Apakah Kemudahan Mendapatkan Produk berpengaruh signifikan terhadap loyalitas merek kartu prabayar IM3 Pada Pegawai Kantor Gubernur Sulawesi Tengah?

\section{KAJIAN PUSTAKA \\ Kepuasan Konsumen}

Menurut Irawan (2002), ada lima driver utama (faktor-faktor pendorong) yang membuat pelanggan merasa puas, yaitu:

1. Kualitas produk

2. Harga

3. Kualitas layanan (service quality)

4. Faktor emosional (Emotional factor)

5. Berhubungan dengan biaya dan kemudahan untuk mendapatkan produk dan jasa

a. Mutu produk

Mutu produk terkait dengan mutu. Mutu adalah keseluruhan ciri dan sifat suatu produk atau pelayanan yang berpengaruh pada kemampuannya untuk memuaskan kebutuhan yang dinyatakan atau yang tersirat. Salah \satu nilai utama yang diharapkan oleh pelanggan dari pemasok adalah mutu produk dan jasa yang tinggi. Dimensi mutu produk dapat berupa fungsi dari produk, penampilan produk, brand image, rentang waktu aman untuk dikonsumsi dan hal lain yang terkait dengan produk.

b. Harga

Bagi pelanggan yang sensitif, harga murah merupakan sumber kepuasan yang penting, karena mendapatkan value of money yang tinggi. Sebaliknya, komponen harga relatif tidak penting bagi yang tidak sensitive terhadap harga. Tujuan Perusahaan Kebutuhan dan Keinginan Pelanggan Produk Ekspektasi Pelanggan terhadap Produk Nilai Produk bagi Pelanggan Tingkat Kepuasan. 
c. Service Quality

Faktor ini sangat tergantung pada tiga hal, yaitu sistem, teknologi dan manusia. Sama seperti mutu produk, maka mutu pelayanan merupakan faktor pendorong yang mempunyai banyak dimensi. Faktor ini mempunyai lima dimensi, yaitu tangible, reliability, responsiveness, assurance dan empathy. Dimensi tangible sangat penting sebagai ukuran pelayanan, karena aspek ini terlihat dan dapat diraba. Reliability merupakan dimensi yang mengukur kehandalan dari perusahaan dalam memberikan pelayanan kepada pelanggan. Ada dua aspek dari dimensi ini, yang pertama adalah kemampuan perusahaan untuk memberikan pelayanan seperti yang dijanjikan dan kedua adalah seberapa jauh suatu perusahaan mampu memberikan pelayanan yang akurat atau tidak ada kesalahan (error). Responsiveness sebagai dimensi ketiga, harus sangat diperhatikan, karena harapan pelanggan terhadap kecepatan pelayanan hampir dapat dipastikan berubah dari waktu ke waktu. Dimensi berikutnya adalah assurance, yaitu dimensi mutu yang berhubungan dengan kemampuan perusahaan dan perilaku front-line staff dalam menanamkan rasa percaya, serta keyakinan kepada para pelanggannya. Dimensi yang terakhir adalah empathy, dimensi ini dipersepsikan kurang penting dibandingkan dimensi reliability dan responsiveness dimata kebanyakan pelanggan. Akan tetapi, untuk kelompok pelanggan kalangan ekonomi menengah ke atas, dimensi ini menjadi paling penting

d. Emotional Factor

Emotional Factor (E-Factor) sebagai faktor pendorong dalam kepuasan pelanggan dibagi menjadi tiga aspek, yaitu estetika, self-expensive value dan brand personality. Aspek estetika meliputi besar kecilnya, bentuk sudut, proporsi dan kesimetrisan. Self-expensive value adalah kepuasan yang timbul karena lingkungan sosial di sekitarnya, seperti kepuasan yang timbul dari penilaian orang lain. Aspek E-Factor yang terakhir adalah brand personality, yang akan memberikan kepuasan kepada konsumen secara internal bergantung dari pandangan orang sekitarnya. Untuk kategori produk yang berhubungan dengan gaya hidup, secara keseluruhan faktor ini cukup penting menentukan kepuasan pelanggan.

e. Kemudahan Mendapatkan Produk

Faktor pendorong terakhir kepuasan pelanggan adalah kemudahan untuk mendapatkan produk atau jasa. Faktor ini berkaitan dengan biaya yang dikeluarkan untuk mendapatkan produk atau jasa. Pelanggan akan semakin puas apabila relatif mudah, nyaman dan efisien dalam mendapatkan produk atau layanan.

\section{Loyalitas}

Pengertian Loyalitas Konsumen Gramer dan Brown (dalam Utomo 2006: 27) memberikan definisi mengenai Loyalitas (loytalitas jasa), yaitu derajat sejauh mana seorang konsumen menunjukkan perilaku pembelian berulang dari suatu penyedia jasa, memiliki suatu desposisi atau kecenderungansikap positif terhadap penyedia jasa, dan hanya mempertimbangkan untuk menggunakan penyedia jasa ini pada saat muncul kebutuhan untuk memakai jasaini. Dari definisi yang disampaikan Gramer dan Brown, konsumen yang loyal tidak hanya seorang pembeli yang melakukan pembelian berulang, tetapi juga mempertahankan sikap positif terhadap penyedia jasa. Menurut Sutisna (2001: 41) Loyalitas konsumen dapat dikelompokkan kedalam dua kelompok yaitu loyalitas merek (brand loyalty) dan loyalitas toko (store loyalty). Loyalitas konsumen dapat didefinisikan sebagai "sikap menyenangi terhadap suatu merek yang direpresentasikan dalam pembelian yang konsisten terhadapmerek itu sepanjang waktu".Loyalitas konsumen didefinisikan Oliver (dalam Taylor, Celuch, dan Goodwin, 1999:218) sebagai komitmen yang tinggi untuk membeli kembali suatu produk atau jasa yang disukai di masa mendatang, disamping pengaruh situasi dan usaha pemasar dalam merubah perilaku. Dengan kata lain konsumen akan setia untuk melakukan pembelian ulang secara terus-menerus. Menurut Wahyu Nugroho (2005:11) loyalitas konsumen didefinisikan sebagai suatu ukuran kesetiaan dari pelanggan dalam menggunakan suatu merek produk atau merek jasa pada kurun waktu tertentu pada situasi dimana banyak pilihan produk ataupun jasa yang dapat memenuhi kebutuhannya dan pelanggan memiliki kemampuan mendapatkannya. 
Berdasarkan beberapa definisi loyalitas konsumen diatas dapat disimpulkan bahwa Loyalitas konsumen adalah kesetiaan konsumen yang dipresentasikan dalam pembelian yang konsisten terhadap produk atau jasa sepanjang waktu dan ada sikap yang baik untuk merekomendasikan orang lain untuk membeli produk. Indikasi loyalitas yang sesunggunhnya diperlukan suatu pengukuran terhadap sikap yang dikombinasikan dengan pengukuran terhadap perilaku. Faktor-Faktor yang Mempengaruhi Loyalitas Konsumen, Marconi (dalam Priyanto Doyo 1998:45) menyebutkan bahwa faktor-faktor yang berpengaruh terhadap suatu produk atau jasa adalah sebagai berikut :

1) Nilai (harga dan kualitas), Kartu prabayar "IM3" dalam waktu yang lama akan mengarahkan pada loyalitas, karena itu pihak perusahaan harus bertanggung jawab untuk menjaga merek tersebut. Perlu diperhatikan, pengurangan standar kualitas dari suatu merek akan mengecewakan konsumen bahkan konsumen yang paling loyal sekalipun begitu juga dengan perubahan harga. Karena itu pihak perusahaan harus mengontrol kualitas merek beserta harganya.

2) Citra (baik dari kepribadian yang dimilikinya dan reputasi dari merek tersebut), citra dari perusahaan dan merek diawali dengan kesadaran. Produk yang memiliki citra yang baik akan dapat menimbulkan loyalitas konsumen pada merek.

3) Kenyamanan dan kemudahan untuk mendapatkan barang dan jasa Dalam situasi Yang penuh tekanan dan permintaan terhadap pasar yang menuntut akan adanya kemudahan, pihak perusahaan dituntut untuk menyediakan produk yang nyaman dan mudah untuk didapatkan.

\section{METODE PENELITIAN}

Penelitian ini berlokasi di Kantor Gubernur Sulawesi Tengah di Kota Palu, dalam penelitian ini difokuskan kepada pengaruh kepuasan konsumen terhadap loyalitas merek kartu prabayar IM3 Pada Kantor Gubernur Sulawesi Tengah di Kota Palu. Waktu penelitian pada bulan Februari - Mei 2018

Populasi.

Populasi adalah gabungan dari seluruh elemen yang berbentuk peristiwa, hal atau orang yang memiliki karakteristik yang serupa yang menjadi pusat perhatian seorang peneliti, karena itu dipandang sebagai sebuah semesta penelitian (Ferdinand, 2006). Menurut Sugiyono (2004) yang dimaksud dengan populasi adalah wilayah generalisasi yang terdiri atas subyek atau obyek yang mempunyai kualitas dan karakteristik tertentu yang ditetapkan oleh peneliti untuk dipelajari dan ditarik kesimpulannya. Populasi dalam penelitian ini adalah mahasiswa pengguna kartu prabayar IM3 Pada Pegawai Kantor Gubernur Sulawesi Tengah.

\section{Sampel}

Sampel adalah subset dari populasi, terdiri dari beberapa anggota populasi (Ferdinand, 2006). Sampel merupakan bagian dari jumlah dan karakteristik populasi tersebut. Besarnya sampel sangat dipengaruhi oleh banyak faktor antara lain tujuan penelitian. Jika penelitian bersifat deskriptif, maka umumnya membutuhkan sampel yang besar, tetapi jika penelitiannya hanya menguji hipotesis dibutuhkan sampel dalam jumlah yang lebih sedikit (Ferdinand 2006). Dalam penelitian ini, penentuan jumlah sampel menggunakan pendekatan Tabachic \& Fidell (2002). Dalam penelitian Multivariate (termasuk yang menggunakan analisis regresi Multivariate) besarnya sampel ditentukan sebanyak 18 kali variabel Independen (Ferdinand, 2006). Jumlah variabel independen dalam penelitian ini adalah 6 , sehingga jumlah sampel yang digunakan adalah 108.

\section{Defenisi Operasional Variabel}

Untuk memperjelas variabel-variabel yang digunakan dalam penelitian ini, dikemukakan batasan-batasan definisi operasional yang akan digunakan sebagai bahan acuan dan dijabarkan dalam bentuk kuesioner. Variabel-variabel sebagai berikut:

Tabel 1

Definisi Opasional Variabel

\begin{tabular}{|c|l|l|c|}
\hline $\begin{array}{c}\mathbf{N} \\
\mathbf{0}\end{array}$ & Variabel & \multicolumn{1}{|l|}{ Indikator } & Skala \\
\hline & & $\begin{array}{l}\text { 1. Jangkauan } \\
\text { wilayah luas }\end{array}$ & $\begin{array}{c}\text { Ordin } \\
\text { al }\end{array}$ \\
$\mathbf{1}$ & $\begin{array}{l}\text { Mutu } \\
\text { Pruduk } \\
\text { (X1) }\end{array}$ & $\begin{array}{l}\text { 2. } \begin{array}{l}\text { Sinyal atau } \\
\text { jaringan } \\
\text { kuat } \\
\text { Kajernihan } \\
\text { suara }\end{array} \\
\text { Suara }\end{array}$ & \\
\hline
\end{tabular}




\begin{tabular}{|c|c|c|c|}
\hline 2 & Harga (X2) & 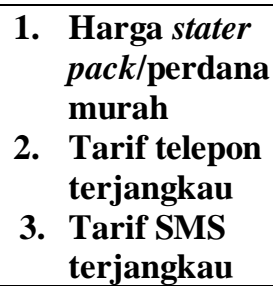 & $\begin{array}{c}\text { Ordin } \\
\text { al }\end{array}$ \\
\hline 3 & $\begin{array}{l}\text { Service } \\
\text { Quality } \\
\text { (X3) }\end{array}$ & 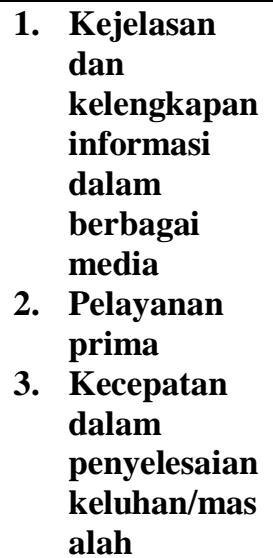 & $\begin{array}{c}\text { Ordin } \\
\text { al }\end{array}$ \\
\hline 4 & $\begin{array}{l}\text { Emotional } \\
\text { Factor }(\mathrm{X} 4)\end{array}$ & $\begin{array}{ll}\text { 1. } & \text { Kemasan } \\
\text { stater } \\
\text { pack/perdana } \\
\text { menarik } \\
\text { 2. Fitur dan } \\
\text { layanan } \\
\text { menarik } \\
\text { 3. Bonus dan } \\
\text { hadiah }\end{array}$ & $\begin{array}{c}\text { Ordin } \\
\text { al }\end{array}$ \\
\hline 5 & $\begin{array}{l}\text { Kemudaha } \\
\text { n } \\
\text { mendapatk } \\
\text { an } \\
\text { Produk } \\
\text { (X5) }\end{array}$ & 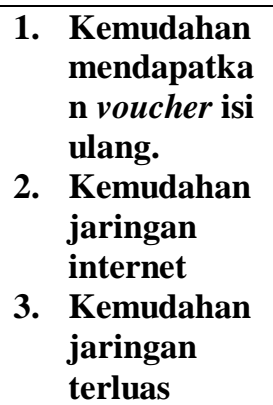 & $\begin{array}{c}\text { Ordin } \\
\text { al }\end{array}$ \\
\hline 6 & $\begin{array}{l}\text { Loyalitas } \\
\text { Merek (Y) }\end{array}$ & $\begin{array}{l}\text { 1. Retension } \\
\text { 2. Redaction } \\
\text { 3. Rekomendati } \\
\text { on }\end{array}$ & $\begin{array}{c}\text { Ordin } \\
\text { al }\end{array}$ \\
\hline
\end{tabular}

\section{Uji Validitas}

Seperti yang dikemukakan oleh Sugiyono (2006; 89) bahwa instrumen yang valid berarti alat ukur yang digunakan untuk mendapatkan data itu valid. Validitas dapat diketahui dengan cara membandingkan nilai corrected item-total correlation dengan nilai $\mathrm{r}$ kritis sesuai kriteria. Menurut Sugiyono (2006;
18), bahwa bilamana koefisien antara skor suatu indikator dengan skor total seluruh indikator adalah positif dan lebih besar $0,3 \quad(r \geq 0,3)$ maka instrument tersebut dianggap valid. Berdasarkan hasil analisis dengan bantuan program SPSS 16.00 telah dilakukan melalui pengujian statistik terhadap variabel Mutu Produk (X1), Harga (X2), Service Quality (X3), Emotional Factor (X4), Kemudahan mendapatkan produk (X5) dan loyalitas merek (Y) secara keseluruhan item pernyataan dinyatakan valid karena seluruh nilai corrected item-total correlation lebih besar dari nilai 0.3 .

\section{Uji Asumsi Klasik}

1. Uji Normalitas.

Model regresi yang baik adalah distribusi data normal atau mendekati normal. Menurut Ghozali (2005; 108) deteksi normalitas dilakukan dengan melihat penyebaran data (titik) pada sumbu diagonal dari grafik.

Dengan menggunakan bantuan program statistik hasil uji normalitas data pada penelitian ini dapat dilihat pada grafik (gambar) di bawah ini:

\section{Gambar 1. Hasil Uji Normalitas}

\section{Normal P-P Plot of Regression Standardized Residual}

\section{Dependent Variable: loyalitas merek}

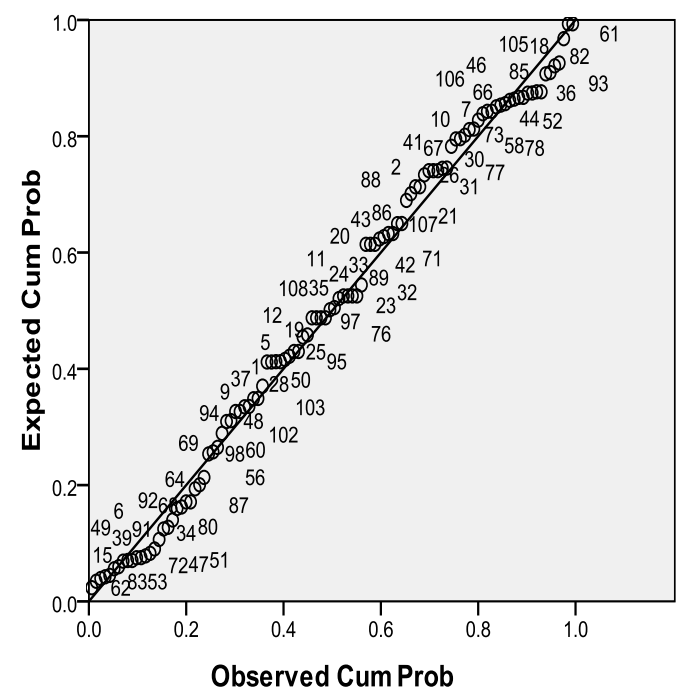


Pada gambar tersebut memperlihatkan bahwa sebaran data mengikuti garis diagonal. Berdasarkan hal tersebut, maka dapat disimpulkan bahwa data yang digunakan dalam analisis regresi ini terdistribusi dengan normal.

2. Uji Multikolinearitas.

Model regresi yang baik seharusnya tidak terjadi korelasi diantara variabel independen. Menurut Ghozali (2005; 105): untuk mengetahuinya adanya multikolinearitas dengan melihat nilai Variance Inflation Factor (VIF). Nilai toleran yang lebih besar dari 0,10 atau nilai VIF lebih kecil dari 10 , maka terjadi multikolinearitas. Hasil uji multikolinearitas dengan menggunakan VIF dan tolerance seperti pada tabel berikut:

Tabel 2. Hasil Uji Multikolinearitas

Tabel 2

Uji Multikolinieritas

\begin{tabular}{|c|l|r|r|}
\hline \multirow{2}{*}{ No } & \multicolumn{1}{|c|}{ Variabel } & \multicolumn{2}{|c|}{$\begin{array}{c}\text { Collinearity } \\
\text { Statistik }\end{array}$} \\
\cline { 3 - 4 } & & Tolerance & \multicolumn{1}{c|}{ VIF } \\
\hline 1 & Mutu Produk & .514 & 1.944 \\
\hline 2 & Harga & .463 & 2.480 \\
\hline 3 & Service Quality & .365 & 2.746 \\
\hline 4 & Emotional Factor & .346 & 2.891 \\
\hline 5 & $\begin{array}{l}\text { Kemudahan } \\
\text { Mendapatkan } \\
\text { Produk }\end{array}$ & & \\
\hline
\end{tabular}

3. Uji Heteroskedastisitas.

Uji heterokedastisitas bertujuan untuk mengetahui apakah variabel pengganggu (distrubance error) mempunyai varians konstan. Uji ini juga untuk menguji apakah dalam model regresi terjadi ketidaksamaan variance dari residual satu pengamatan ke pengamatan lainnya.

Hasil uji heterokedastisitas dari model regresi yang terbentuk tersaji pada gambar berikut:
Gambar 2. Hasil Uji Heteroskedastisitas

Scatterplot

Dependent Variable: loyalitas merek

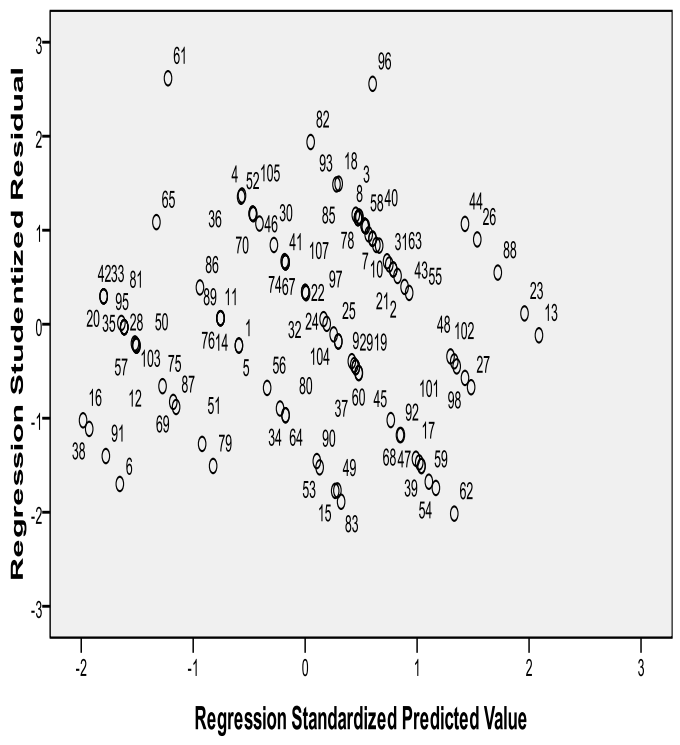

Berdasarkan Gambar di atas terlihat titiktitik menyebar secara acak, tidak membentuk sebuah pola tertentu yang jelas, serta tersebar baik di atas maupun dibawah angka 0 pada sumbu Y. Hal ini memberi makna bahwa persamaan regresi memenuhi asumsi heteroskedastisitas.

\section{HASIL DAN PEMBAHASAN \\ Hasil Pengujian Regresi}

Analisis regresi linear berganda dalam penelitian ini digunakan untuk mengetahui pengaruh faktor Mutu Produk (X1), Harga (X2), Service Quality (X3), Emotional Factor (X4), dan kemudahan mendapatkan produk (X5) terhadap Loyalitas Merek Kartu Prabayar IM3 Pada Pegawai Kantor Gubernur Sulawesi Tengah berdasarkan pengujian doperoleh hasil sebagai berikut: 
Tabel 3

Hasil Pengujian Regresi Linear Berganda

\begin{tabular}{|c|c|c|c|c|c|}
\hline \multirow[t]{2}{*}{$\begin{array}{l}\mathrm{N} \\
\mathrm{o}\end{array}$} & \multicolumn{5}{|c|}{$\begin{array}{c}\text { Faktor Terikat }=\text { Keputusan Konsumen } \\
\text { Membeli }(\mathrm{Y})\end{array}$} \\
\hline & Variabel & (Beta) & $\begin{array}{l}\text { Std. } \\
\text { Error }\end{array}$ & t-hit & Sig.t \\
\hline & (Constant) & 1.743 & .866 & 2.014 & .047 \\
\hline 1 & (X1) & .201 & .079 & 2.554 & .012 \\
\hline 2 & $(\mathrm{X} 2)$ & .314 & .099 & 3.169 & .002 \\
\hline 3 & (X3) & 141 & 073 & 1.942 & .045 \\
\hline 4 & (X4) & 306 & .078 & 3.899 & .000 \\
\hline 5 & (X5) & .108 & .094 & 1.905 & .048 \\
\hline \multicolumn{6}{|c|}{$\mathrm{n}=108$} \\
\hline \multicolumn{6}{|c|}{ Konstanta $=1.743$} \\
\hline \multicolumn{6}{|c|}{ Koefesien Korelasi $(\mathrm{R})=0,873$} \\
\hline \multicolumn{6}{|c|}{ Koefisien Determinasi $\left(\mathrm{R}^{2}\right)=0,762$} \\
\hline \multicolumn{6}{|c|}{ F-Statistik $=65.189$} \\
\hline \multicolumn{6}{|c|}{ Sig. $F=0,000$} \\
\hline
\end{tabular}

Sumber: Lampiran

Dari hasil pengujian dengan menggunakan regresi linier berganda di atas, maka dapat disusun persamaan regresi berganda dari pengaruh mutu produk, harga, service quality, emotional factor dan kemudahan mendapatkan produk terhadap loyalitas merek kartu prabayar IM3 pada pegawai Kantor Gubernur Sulawesi Tengah yaitu:

$\mathrm{Y}=1,743+0,201 \mathrm{X} 1+0,314 \mathrm{X} 2+0,141 \mathrm{X} 3+$ $0,306 \mathrm{X} 4+0,108 \mathrm{X} 5+\mathrm{e}$

Hasil pengujian di atas menunjukan, di mana nilai konstanta 1, 743 merupakan bilangan tepat yang berarti terjadi pengaruh mutu produk (X1), harga (X2), service quality (X3), emotional factor (X4), dan kemudahan mendapatkan produk (X5) terhadap loyalitas merek kartu prabayar IM3 pada pegawai Kantor Gubernur Sulawesi Tengah yaitu 1,743 .

Selanjutnya koefisien regresi faktor mutu produk (X1) sebesar 0,201 memberikan arti bahwa jika terjadi perubahan X1 sebesar satu satuan maka loyalitas merek kartu IM3 akan terjadi pula perubahan terhadap lotalitas merek kartu IM3 pilihan konsumen sebesar 0,201 dan dengan asumsi variabel lain diangap konstan terjadi pengaruh sebesar 0,201 atau $20,1 \%$ terhadap Loyalitas Merek Kartu Prabayar IM3 pada pegawai Kantor Gubernur Sulawesi Tengah. Koefesien regresi faktor harga (X2) memberikan arti bahwa terjadi pengaruh sebesar 0,314 atau $31,4 \%$ terhadap loyalitas merek kartu prabayar
IM3 pada pegawai Kantor Gubernur Sulawesi Tengah. Koefisien regresi service quality (X3) memberikan arti bahwa terjadi pengaruh sebesar 0,141 atau $14,1 \%$ terhadap loyalitas merek kartu prabayar IM3 pada pegawai Kantor Gubernur Sulawesi Tengah. Koefisien regresi emotional factor (X4) memberikan arti bahwa terjadi pengaruh sebesar 0,306 atau 30,6\% terhadap loyalitas merek kartu prabayar IM3 pada pegawai Kantor Gubernur Sulawesi Tengah. Dan koefisien regresi kemudahan mendapatkan produk (X5) memberikan arti bahwa terjadi pengaruh sebesar 0,108 atau $10,8 \%$ terhadap loyalitas merek kartu prabayar IM3 pada pegawai Kantor Gubernur Sulawesi Tengah.

Multiple atau koefisien korelasi (R) adalah hubungan antara kelima variabel bebas yaitu mutu produk, harga, service quality, emotional factor dan kemudahan mendapatkan produk terhadap loyalitas merek kartu prabayar IM3 sebesar 0,873 atau 87,3\% artinya hubungan variabel bebas (independen) terhadap variabel terikat (dependen) adalah sangat kuat.

R Square atau koefisien determinasi $\left(\mathrm{R}^{2}\right)$ adalah melihat pengaruh antara kelima variabel bebas yaitu mutu produk, harga, service quality, emotional factor dan kemudahan mendapatkan produk terhadap loyalitas merek kartu prabayar IM3 sebesar 0,762 atau 76,2\% artinya pengaruh variabel bebas (independen) terhadap variabel terikat (dependen). Sedangkan sisanya 23,8\% adalah pengaruh variabel lain yang tidak diteliti dalam penelitian ini.

\section{PEMBUKTIAN HIPOTESIS}

\section{Pembuktian Hipotesis Pertama}

Hipotesis pertama yaitu pengaruh mutu produk, harga, service quality, emotional factor dan kemudahan mendapatkan produk terhadap loyalitas merek kartu prabayar IM3 pada pegawai Kantor Gubernur Sulawesi Tengah. Pembuktian hipotesis pertama mengguanakan uji $\mathrm{F}_{\text {sig. }}$. Nilai signifikansi $0,000<\alpha 0,05$. Maka terbukti kelima variabel bebas yaitu mutu produk, harga, service quality, emotional factor dan kemudahan mendapatkan produk berpengaruh secara serempak terhadap loyalitas merek kartu prabayar IM3 pada pegawai Kantor Gubernur Sulawesi Tengah. Dengan hasil penelitian ini maka diambil keputusan hipotesis pertama dalam penelitian ini telah terbukti dan dapat diterima. 


\section{Pembuktian Hipotesis Kedua}

Hipotesis kedua yaitu untuk mengetahui apakah variabel mutu produk (X1), secara parsial berpengaruh signifikan terhadap loyalitas merek kartu prabayar IM3 pada pegawai Kantor Gubernur Sulawesi Tengah.

Dari tabel 3 diatas bahwa besarnya probabilitas signifikansi variabel mutu produk (X1) adalah $0,012<$ taraf signifikan yang diisyaratkan $\alpha 0,05$. Dengan demikian bahwa secara statistik variabel mutu produk dalam penelitian ini memberikan pengaruh yang signifikan terhadap loyalitas merek kartu prabayar IM3 pada pegawai Kantor Gubernur Sulawesi Tengah.

\section{Pembuktian Hipotesis Ketiga}

Hipotesis ketiga yaitu untuk mengetahui apakah variabel Harga (X2), secara parsial berpengaruh signifikan terhadap loyalitas merek kartu prabayar IM3 pada pegawai Kantor Gubernur Sulawesi Tengah.

Dari tabel 3 bahwa besarnya probabilitas signifikansi variabel harga (X2) adalah 0,002 < taraf signifikan yang diisyaratkan $\alpha 0,05$. Dengan demikian bahwa secara statistik variabel harga dalam penelitian ini memberikan pengaruh yang signifikan terhadap loyalitas merek kartu prabayar IM3 pada pegawai Kantor Gubernur Sulawesi Tengah.

\section{Pembuktian Hipotesis Keempat}

Hipotesis keempat yaitu untuk mengetahui apakah variabel service quality (X3), secara parsial berpengaruh signifikan terhadap loyalitas merek kartu prabayar IM3 pada pegawai Kantor Gubernur Sulawesi Tengah.

Dari tabel 3 diatas bahwa besarnya probabilitas signifikansi variabel service quality (X3) adalah $0,045<$ taraf signifikan yang diisyaratkan $\alpha 0,05$. Dengan demikian bahwa secara statistik variabel service quality dalam penelitian ini memberikan pengaruh yang signifikan terhadap loyalitas merek kartu prabayar IM3 pada pegawai Kantor Gubernur Sulawesi Tengah.

\section{Pembuktian Hipotesis Kelima}

Hipotesis kelima yaitu untuk mengetahui apakah variabel emotional factor (X4), secara parsial berpengaruh signifikan terhadap loyalitas merek kartu prabayar IM3 pada pegawai Kantor Gubernur Sulawesi Tengah.

Dari tabel 3 diatas bahwa besarnya probabilitas signifikansi variabel emotional factor (X4) adalah
$0,000<$ taraf signifikan yang diisyaratkan $\alpha 0,05$. Dengan demikian bahwa secara statistik variabel emotional factor dalam penelitian ini memberikan pengaruh yang signifikan terhadap loyalitas merek kartu prabayar IM3 pada pegawai Kantor Gubernur Sulawesi Tengah.

\section{Pembuktian Hipotesis Keenam}

Hipotesis keenam yaitu untuk mengetahui apakah variabel kemudahan mendapatkan produk (X5), secara parsial berpengaruh signifikan terhadap loyalitas merek kartu prabayar IM3 pada pegawai Kantor Gubernur Sulawesi Tengah.

Dari tabel 3 diatas bahwa besarnya probabilitas signifikansi variabel kemudahan mendapatkan produk (X5) adalah 0,048 < taraf signifikan yang diisyaratkan $\alpha 0,05$. Dengan demikian bahwa secara statistik variabel kemudahan mendapatkan produk dalam penelitian ini memberikan pengaruh yang signifikan terhadap loyalitas merek kartu prabayar IM3 pada pegawai Kantor Gubernur Sulawesi Tengah.

\section{PEMBAHASAN}

Hasil pembuktian hipotesis dalam penelitian ini pengaruh mutu produk, harga, service quality, emotional factor dan kemudahan mendapatkan produk terhadap loyalitas merek kartu prabayar IM3 pada pegawai Kantor Gubernur Sulawesi Tengah memberikan pembuktian bahwa kelima variabel independen yaitu mutu produk, harga, service quality, emotional factor dan kemudahan mendapatkan produk memilki pengaruh secara signifikan terhadap loyalitas merek. Dengan demikian dinyatakan bahwa hipotesis mengenai pengaruh mutu produk, harga, service quality, emotional factor dan kemudahan mendapatkan produk terhadap loyalitas merek kartu prabayar IM3 Pada Pegawai Kantor Gubernur Sulawesi Tengah dapat diterima.

Pengaruh mutu produk, harga, service quality, emotional faktor dan kemudahan mendapatkan produk Terhadap Loyalitas Merek Kartu Prabayar IM3 pada Pegawai Kantor Gubernur Sulawesi Tengah.

Hasil penelitian membuktikan bahwa penelitian ini seluruh faktor independen berpengaruh positif terhadap loyalitas merek kartu prabayar IM3 pada pegawai Kantor Gubernur Sulawesi Tengah. Artinya jika kelima variabel tersebut diperlukan dalam waktu bersamaan, maka hal tersebut menimbulkan peningkatan loyalitas merek kartu 
prabayar IM3 pada pegawai Kantor Gubernur Sulawesi Tengah.

Hubungan Mutu Produk Dan Loyalitas Merek
Kartu Prabayar IM3 Pada Pegawai Kantor
Gubernur Sulawesi Tengah. Mutu produk terkait dengan mutu. Mutu adalah keseluruhan ciri dan sifat suatu produk atau pelayanan yang berpengaruh pada kemampuannya untuk memuaskan kebutuhan yang dinyatakan atau yang tersirat. Salah $\backslash s a t u$ nilai utama yang diharapkan oleh pelanggan dari pemasok adalah mutu produk dan jasa yang tinggi. Dimensi mutu produk dapat berupa fungsi dari produk, penampilan produk, brand image, rentang waktu aman untuk dikonsumsi dan hal lain yang terkait dengan produk. Dengan meningkatkan mutu produk maka akan mempertahan konsumen untuk tetap loyal untuk mengunakan kartu prabayar IM3 khusunya bagi pegawai Kantor Gubernur Sulawesi Tengah.

Hubungan Harga Dan Loyalitas Merek Kartu Prabayar IM3 Pada Pegawai Kantor Gubernur Sulawesi Tengah.

Bagi pelanggan yang sensitif, harga murah merupakan sumber kepuasan yang penting, karena mendapatkan value of money yang tinggi. Sebaliknya, komponen harga relatif tidak penting bagi yang tidak sensitive terhadap harga. tujuan perusahaan kebutuhan dan keinginan pelanggan produk ekspektasi pelanggan terhadap produk nilai produk bagi pelanggan tingkat kepuasan. Dengan demikian harga yang murah dapat mempertahankan konsumen agar tetap loyal mengunakan kartu prabayar IM3 dan menjadi pilihan utama konsumen.

Hubungan Service Quality Dan Loyalitas Merek Kartu Prabayar IM3 Pada Pegawai Kantor Gubernur Sulawesi Tengah.

Faktor ini sangat tergantung pada tiga hal, yaitu sistem, teknologi dan manusia. Sama seperti mutu produk, maka mutu pelayanan merupakan faktor pendorong yang mempunyai banyak dimensi. Faktor ini mempunyai lima dimensi, yaitu tangible, reliability, responsiveness, assurance dan empathy. Dimensi tangible sangat penting sebagai ukuran pelayanan, karena aspek ini terlihat dan dapat diraba. Reliability merupakan dimensi yang mengukur kehandalan dari perusahaan dalam memberikan pelayanan kepada pelanggan. Ada dua aspek dari dimensi ini, yang pertama adalah kemampuan perusahaan untuk memberikan pelayanan seperti yang dijanjikan dan kedua adalah seberapa jauh suatu perusahaan mampu memberikan pelayanan yang akurat atau tidak ada kesalahan (error). Responsiveness sebagai dimensi ketiga, harus sangat diperhatikan, karena harapan pelanggan terhadap kecepatan pelayanan hampir dapat dipastikan berubah dari waktu ke waktu. Dimensi berikutnya adalah assurance, yaitu dimensi mutu yang berhubungan dengan kemampuan perusahaan dan perilaku front-line staff dalam menanamkan rasa percaya, serta keyakinan kepada para pelanggannya. Dimensi yang terakhir adalah empathy, dimensi ini dipersepsikan kurang penting dibandingkan dimensi reliability dan responsiveness dimata kebanyakan pelanggan. Akan tetapi, untuk kelompok pelanggan kalangan ekonomi menengah ke atas, dimensi ini menjadi paling penting. Dengan service quality yang baik maka konsumen akan tetap bertahan mengunakan kartu prabayar IM3 sebagai pilihan utama konsumen.

Hubungan Emotional Factor Dan Loyalitas Merek Kartu Prabayar IM3 Pada Pegawai Kantor Gubernur Sulawesi Tengah.

Emotional Factor (E-Factor) sebagai faktor pendorong dalam kepuasan pelanggan dibagi menjadi tiga aspek, yaitu estetika, self-expensive value dan brand personality. Aspek estetika meliputi besar kecilnya, bentuk sudut, proporsi dan kesimetrisan. Self-expensive value adalah kepuasan yang timbul karena lingkungan sosial di sekitarnya, seperti kepuasan yang timbul dari penilaian orang lain. Aspek E-Factor yang terakhir adalah brand personality, yang akan memberikan kepuasan kepada konsumen secara internal bergantung dari pandangan orang sekitarnya. Untuk kategori produk yang berhubungan dengan gaya hidup, secara keseluruhan faktor ini cukup penting menentukan kepuasan pelanggan. Dengan mengunakan emotional service sebagai promosi yang baik perusahaan maka akan meningkatkan penjualan kartu prabayar IM3 dan dapat mempertahan kan konsumen untuk tetap mengunakan kartu IM3. 
Hubungan Kemudahan Mendapatkan Produk Dan Loyalitas Merek Kartu Prabayar IM3 Pada Pegawai Kantor Gubernur Sulawesi Tengah.

Faktor pendorong terakhir kepuasan pelanggan adalah kemudahan untuk mendapatkan produk atau jasa. Faktor ini berkaitan dengan biaya yang dikeluarkan untuk mendapatkan produk atau jasa. Pelanggan akan semakin puas apabila relatif mudah, nyaman dan efisien dalam mendapatkan produk atau layanan. Konsumen akan tetap memilih produk IM3 karena mudah untuk mendapatkan produk tersebut sehingga konsumen akan tetap mengunakan kartu prabayar tersebut dan menjadi pilihan utama konsumen

\section{KESIMPULAN}

\section{Kesimpulan}

Berdasarkan hasil pembahasan dan hasil olahan data pada penelitian ini, maka kesimpulan yang dapat ditarik adalah sebagai berikut:

1. Mutu produk, harga, service quality, emotional factor dan kemudahan mendapatkan produk secara serempak berpengaruh signifikan terhadap loyalitas merek kartu prabayar IM3 pada pegawai Kantor Gubernur Sulawesi Tengah.

2. Mutu produk berpengaruh signifikan terhadap loyalitas merek kartu prabayar IM3 pada pegawai Kantor Gubernur Sulawesi Tengah.

3. Harga berpengaruh signifikan terhadap loyalitas merek kartu prabayar IM3 pada pegawai Kantor Gubernur Sulawesi Tengah.

4. Service Quality berpengaruh signifikan terhadap loyalitas merek kartu prabayar IM3 pada pegawai Kantor Gubernur Sulawesi Tengah.

5. Emotional Factor berpengaruh signifikan terhadap loyalitas merek kartu prabayar IM3 pada pegawai Kantor Gubernur Sulawesi Tengah.

6. Kemudahan Mendapatkan Produk berpengaruh signifikan terhadap loyalitas merek kartu prabayar IM3 pada pegawai Kantor Gubernur Sulawesi Tengah.

\section{Saran-Saran}

Berdasarkan kesimpulan yang di ambil, maka penulis memberikan saran sebagai berikut:

1. Hendaknya menjadikan Mutu Produk, Harga, Service Quality, Emotional Factor dan Kemudahan Mendapatkan Produk sebagai hal prioritas yang harus ditingkatkan agar dapat meningkatkan penjualan kartu prabayar IM3 di Kota Palu khususnya bagi pegawai Kantor Gubernur Sulawesi Tengah.

2. Perusahaan harus memperbanyak agen-agen IM3 agar konsumen mudah mendapatkan kartu prabayar IM3.

3. Perusahaan harus lebih meningkatkan kualitas pelayanannya khususnya dalam akses internet agar pengguna makin loyal terhadap penggunaan kartu IM3..

\section{DAFTAR PUSTAKA}

Basu Swasta, 2002. Manajemen Pemasaran Modern, Yogyakarta. Liberty.

Barry Berman dan Joel R. Evans 2007. Retail Management. USA. Pearson Prentice Hall.

David L. Kurtz, 2010. Principle Of Contemporary Marketing, 14 th Edition. South Western.

Dinarty SH Manurung, 2009. Pengaruh Kepuasan Konsumen Terhadap Loyalitas Merek Terhadap Penguna Kartu Prabayar Simpati. Fakultas Psikologi Universitas Sumatra Utara.

Francis Buttle, 2007. Custumer Relationship Management. Concept and Tools Pearson Prentice Hall.

Giddens Nancy \& Hofmann, 2002 Brand Loyalty. Amanda.

Gary Amstrong dan Philip Kotler, 2009. Marketing USA. Pearson Prentice Hall.

Haryanti, 2005. Analisis Kepuasan Dan Loyalitas Konsumen Terhadap Hendphone Sony Ericson, Bogor.

Hawkins, 2010. Consumer Bihavior. Bilding Marketing Strategy, Elevent Edition New York.

Husein Umar, 2002 Riset Pemasaran Dan Perilaku Konsumen, PT. Gramedia Pustaka Utama. Jakarta.

Irawan H, 2002. 10 Prinsip Kepuasan Pelangan. PT. Elex Media Kumpotindo, Jakarta.

John C. Women dan Michael Minor, 2002. Perilaku Konsumen Edisi Kelima. Jilid 2. Penerbit Airlanga. Jakarta.

Kotler Philip, 2007. Manajemen Pemasaran Edisi 12 PT. Indeks Jakarta.

Kotler Philip, 2008. Prinsip-Prinsip Pemasaran Edisi 12 Jilid 1. PT. Indeks Jakarta.

Kotler Philip, 2009. Marketing Management PT. Indeks Jakarta.

Marconi, 2002. Mengukur Kepuasan Pelangan Panduan Menciptakan Pelayanan Bermutu. Penerbit PPM. Jakarta. 
Pasaribu, 2005. Pengaruh Tingkat Kepuasan Pelangan Terhadap Penguna Kartu Simpati, Bogor.

Paul J Peter dan Jerry C Olson, 2010. Custumer Behavior And Marketing Strategy. Ninth Edition. New York.

Richard Gerson, 2002. Mengukur Kepuasan Pelangan Panduan Menciptakan Pelayanan Bermutu. Penerbit PPM. Jakarta.

Robert F Lusch Patrick M Dunne and James R Carver, 2011. Introduksion to Retailing Seventh Edition. South Western.

Simmamora Bilson, 2002. Aura Merek (7 Langkah Membangun Merek Kuat). PT. Gramedia Pustaka Utama. Jakarta.

Simmamora Bilson, 2004. Riset Pemasaran PT. Gramedia Pustaka Utama. Jakarta.

Suryana, 2007. Pengaruh Tingkat Kepuasan Dan Loyalitas Konsumen Terhadap Produk Minuman Isotonic Merek Pocari Sweet, Bogor.

Valaire A Zeihhaml, Mary Jo Bitner dan Dwayne D Gremler, 2009. Service Marketing. New York. 